2. To: (Receiving ()rganization)
RPP Characterization Engineering

5. Proj./Prog./Dept./Div.:

Characterization Project

8. Originator Renarks:

This EDT releases a Configuration Management Plan for the LLCERS RT and TT.

11. Receiver Remarks:
3. l'rom: (Originating Organization)
RPP Characterization Engineering

6. Design Authority/Design Agent/Cog. Fingr.: GP Janicek/RN Dale

\begin{tabular}{c|r}
\multirow{2}{*}{ 4. Related EDT No:: } \\
N/A
\end{tabular}

10. System/Bldg./Facility:

$200 \mathrm{G}$

12. Major $\Lambda$ ssm. Dwg. No.

$\mathrm{N} / \mathrm{A}$

13. Permil/Permit Application No.:

$\mathrm{N} / \mathrm{A}$

14. Required Response Date

ASAP

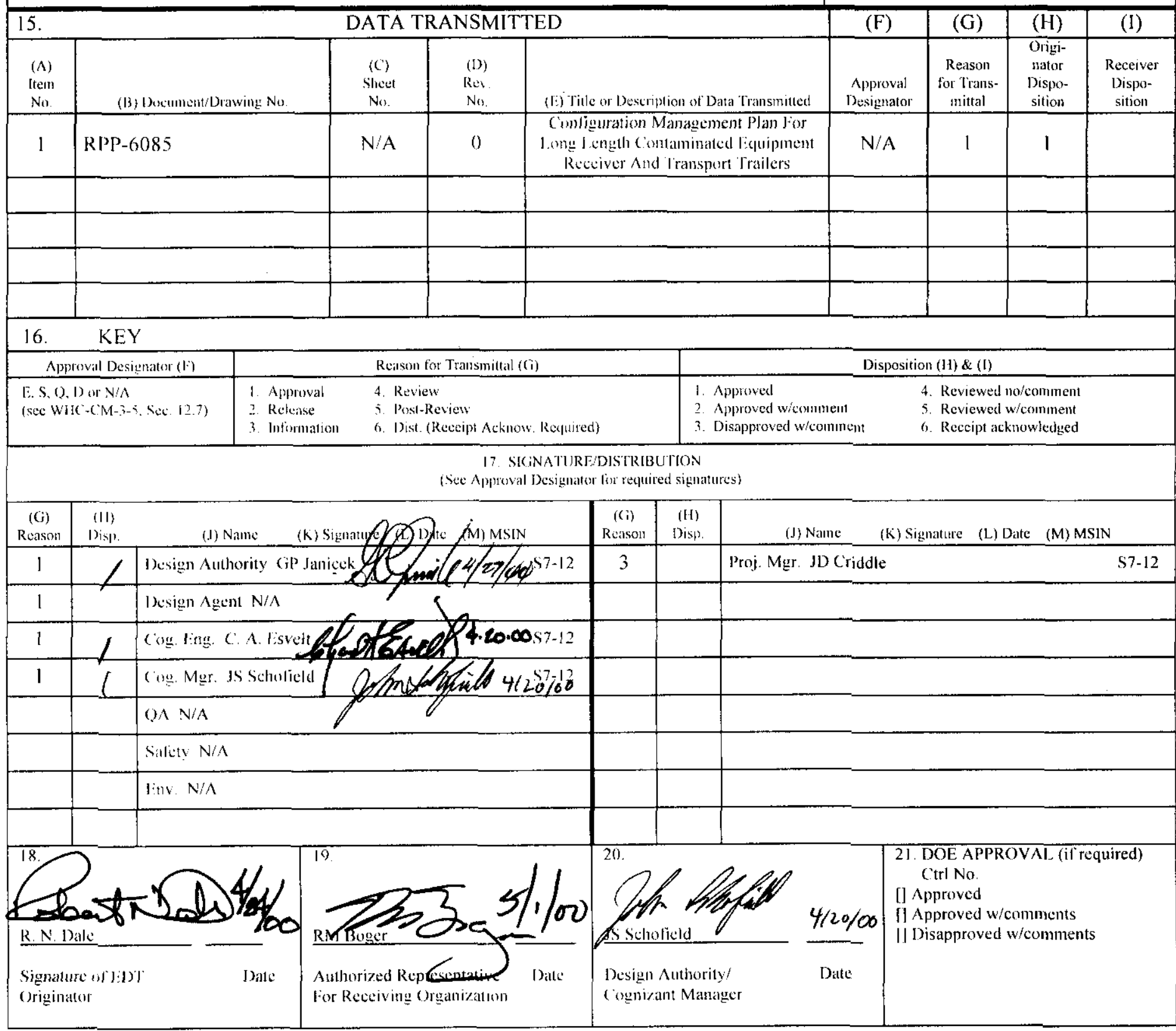




\title{
CONFIGURATION MANAGEMENT PLAN FOR LONG LENGTH CONTAMINATED EQUIPMENT RECEIVER AND TRANSPORT TRAILERS
}

\author{
R. N. Dale \\ Prepared by CH2MHILL Hanford Group, Inc. \\ Richland, WA 99352 \\ U.S. Department of Energy Contract DE-AC06-96RL13200 \\ $\begin{array}{lll}\text { EDT/ECN: } & 628738 & \text { UC: } 2000 \\ \text { Org Code: } & 74900 & \text { Charge Code: } \\ \text { B\&R Code: } & \text { EW } 3130000 & \text { Total Pages: } \boldsymbol{q}^{\frac{110337}{25 / 1 / 00}}\end{array}$
}

Key Words: LLCERS Receiver Trailer, Transport Trailer Configuration Manag ement Plan, TWRS, RPP

Abstract: Long Length Contaminated Equipment Removal System Receiver Trail er and Transport Trailer require a configuration management plan for design, requirements and operations baseline documents. This report serves as the plan for the Trailers.

TRADEMARK DISCLAIMER. Reference herein to any specific commercial product, process, or service by trade name trademark, manufacturer, or otherwise, does not necessarily constitute or imply its endorsement, recommendation, or favoring by the United States Government or any agency thereof or its contractors or subcontractors.

Printed in the United States of America. To obtain copies of this document, contact: Document Control Services, P.O. Box 950, Mailstop H6-08, Richland WA 99352, Phone (509) 372-2420; Fax (509) 376-4989.
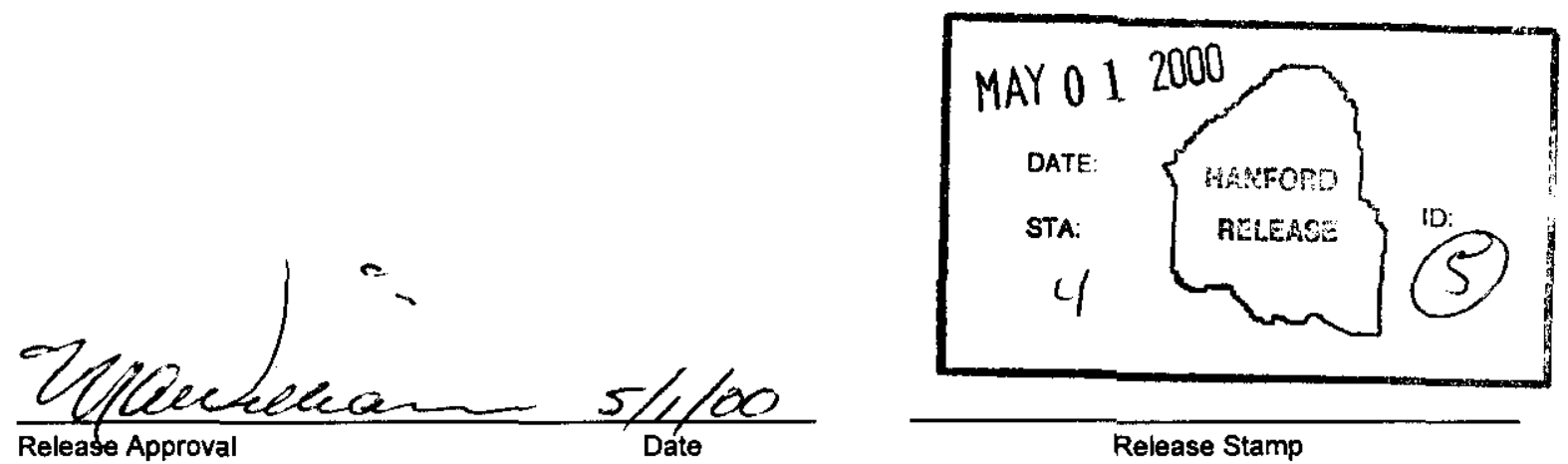

\section{Approved For Public Release}


RPP-6085, Rev. 0

Configuration Management Plan For Long Length Contaminated Equipment Receiver And Transport Trailers

Prepared for CH2M Hill Hanford Group, Inc.

Characterization Field Engineering Group

By

G. P. Janicek and R. N. Dale

CH2M HILL Hanford Group, Inc.

April, 2000 


\section{TABLE OF CONTENTS}

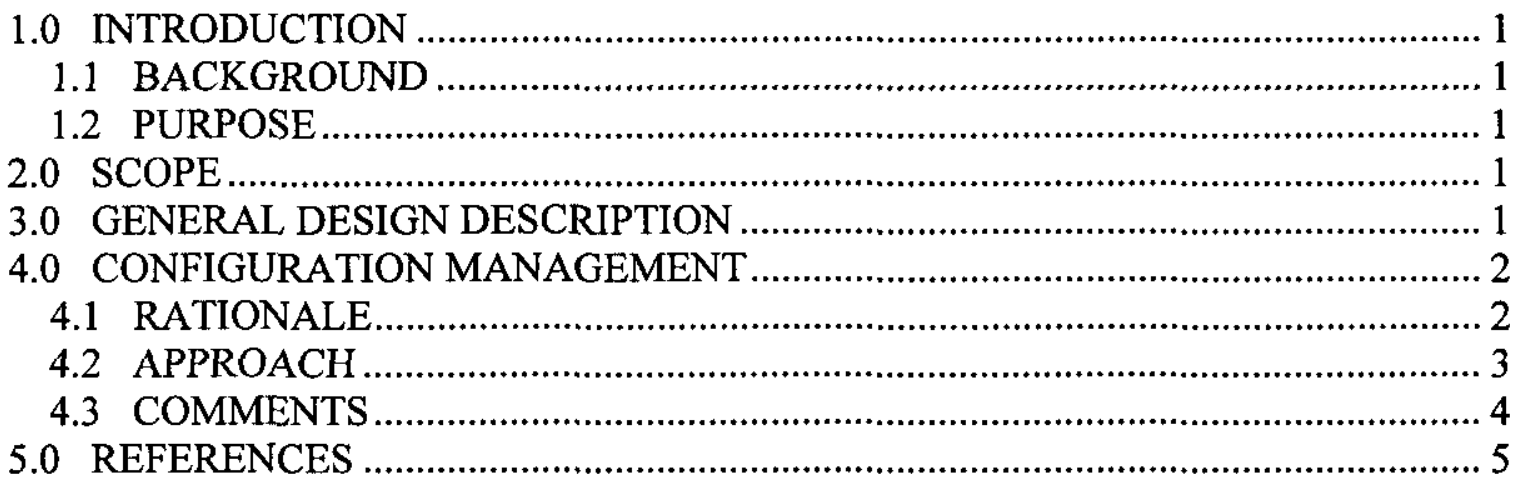




\section{CONFIGURATION MANAGEMENT PLAN \\ FOR LONG LENGTH CONTAMINATED EQUIPMENT \\ RECEIVER AND TRANSPORT TRAILERS}

\subsection{INTRODUCTION}

\subsection{BACKGROUND}

A system to accommodate the removal of long-length contaminated equipment (LLCE) from Hanford underground radioactive waste storage tanks was designed, procured, and demonstrated, via a project activity during the 1990s. The Long Length Contaminated Equipment Removal System (LLCERS) will be maintained and operated by Tank Farms Engineering and Operations organizations and other varied projects having a need for the system. Presently, stewardship of major portions of the LLCERS has been assigned to the Characterization Engineering Group within Plant Engineering, as described in RPP3654, "Engineering Task Plan (ETN-98-0007) Stewardship of LLCERS"..

\subsection{PURPOSE}

The purpose of this document is to identify the design, requirements, and operations baseline documents for the applicable LLCERS components. The configuration management plan for the equipment is also defined.

\subsection{SCOPE}

The LLCERS is composed of a number of separate components acting together for the purpose of removing LLCE from Hanford nuclear waste tanks. This document is only applicable to the Receiver Trailer (RT) and the Transport Trailer (TT) that were procured in the mid 1990s per procurement specification WHC-S-0321, Rev. 2-B. These two major system components are replacement trailers for those used during the original demonstration project. The design of the new trailers, that are the subject of this design report, has been changed from the original receiver and transport trailers to increase the reliability and ease of operation. Any modifications to the RT and TT will be performed and documented as outlined by this document.

\subsection{GENERAL DESIGN DESCRIPTION}

LLCE to be removed from underground waste tank risers is expected to range in length from 12 feet to 55 feet. Actual removal will be performed using cranes dedicated to tank farm service. Coincident with removal of the LLCE from the tank riser, the LLCE will be sleeved with a heavy plastic material and tied at each end to confine any radioactive or toxic contamination remaining after spray washing. The crane will then transport the LLCE to a skid on the RT. 
The Receiver Trailer is outfitted with a "skid and strong back" to receive the contained LLCE. The skid is locked onto the strong back which is hydraulically raised and lowered to interface with the crane. It is placed in the raised, vertical, position to receive the LLCE from the crane, and is then lowered to a horizontal position in conjunction with the lowering of the LLCE by the crane. The RT is also outfitted with a winch driven "tug" that transfers the LLCE onto the TT. The function of the tug is to push the contained LLCE and skid from on-board the Receiver Trailer into a burial container on board the Transport Trailer. The RT is aligned and leveled to mate with the TT to perform this operation.

The Transport Trailer is outfitted with a structure, (chocks and tie down ratchet straps), that holds a burial container into which the LLCE package is placed. Once the LLCE package is transferred from the Reciever Trailer to the burial container the container is sealed. The TT then transports the LLCE package to a storage or burial site, for removal by another crane.

\subsection{CONFIGURATION MANAGEMENT}

\subsection{RATIONALE}

Configuration management, with reference to the Hanford site, entails establishing and controlling the modification of the requirements, design, and operational baselines (controlling configuration) for all DOE owned facility systems, structures, and components (SSCs). The primary purpose of configuration management is to ensure the safety of the public and site personnel, and to provide protection for DOE property. The rigor with which configuration management is applied is graded according to the category or classification of facilities and SSCs. Categories for grading usually consider "permanent vs. temporary", "nuclear vs. non-nuclear", and may consider "fixed vs. mobile", "occupied vs. unoccupied", "programmatic risk", "initial/replacement cost", etc. Classifications for grading consider "Safety Class (SC) vs. Safety Significant (SS) vs. General Service (GS)" when referring to nuclear facility SSCs. [Note: SC, SS, and GS are defined in terms of a safety classification system for nuclear facility SSCs and are not applicable to non-nuclear facility SSCs.]

The RPP procedures that govern configuration management of the design baseline include RPP-PRO-1819, "Engineering Requirements", HNF-IP-0842, Vol. IV, section 3.5, "Engineering Documents", section 4.23, "Vendor Information", section 4.24, "Design Verification", section 4.25, "Engineering Drawings", and section 4.29, "Engineering Document Change Control Requirements". These procedures contain the explicit statement that "H-series drawings shall be used to depict permanent facilities, structures, systems, and components". The procedures implicitly require that $\mathrm{H}$-series drawings also be used to depict nuclear facility SSCs. In addition, the procedures, state that vendor drawings can be used to document "permanent" or "temporary" facility 
SSCs, and "nuclear" or "non-nuclear" facility SSCs; and, thus, can be utilized in a graded manner, with regard to design configuration management.

The RT and TT do not fall into the category of a "permanent" facility. Therefore, they do not require H-series drawings. The RT and TT are not "nuclear" facilities, nor are they part of a "nuclear" facility at any time during their use. Thus they would not require $\mathrm{H}$ series drawings. Consequently, "drawings" that modify, or add to, the design, requirements or operations baseline documents for the RT and TT are not required to be $\mathrm{H}$-series drawings. [Note: The configuration of the LLCE burial container and associated hardware is controlled with $\mathrm{H}$-series drawings because it is analyzed and credited for compliance with DOT requirements in HNF-SD-TP-SARP-013, "Safety Analysis Report for Packaging (Onsite) Long Length Contaminated Equipment".]

Configuration management of the RT and TT is necessary. The remainder of this section defines the configuration management plan for these two pieces of equipment.

\subsection{APPROACH}

All vendor-furnished, RT and TT documentation including hardcopy "drawings", electronic data sets (CAD files), and the "LLCE Trailers Operations and Maintenance Manual" will be incorporated into a Vendor Information (VI) file which will be maintained in the Hanford Document Control System. The VI file will be maintained for historical purposes only, i.e., to document the precise materials and component configuration received from the vendor in response to the procurement specification for the RT and TT. The documents in the VI file will not be used to control the configuration of the RT and TT, will not be distributed, and will not be updated. The VI file will have a copy of this Configuration Management Plan included in it so that anyone may determine the means of configuration management for the RT and TT. The VI file will only be used as a reference source for the equipment as originally received.

Configuration Management for the RT and TT will be accomplished by exercising change control over the supporting documents that constitute the design, requirements and operational baselines.

The Design baseline for the LLCERS RT and TT is defined by:

RPP-6189, "Long Length Contaminated Equipment Retreival System Trailers Drawings". This document is a subset of the VI file drawings. The drawings in this supporting document are the VI file drawings identified as being required to maintain configuration control for the LLCERS Receiver Trailer and Transport Trailer. Many of the drawings would be considered "essential" in reference to $\mathrm{H}$ series drawings. Drawings included in RPP-6189 are, P\&IDs, electrical elementary and one-line diagrams, hydraulic diagrams, and others, as needed, to complete an understanding of the RT and TT Operations and Maintenance (O \& M) Manual instructions. Three copies of this document, with attached active Engineering Change Notices, will be maintained in the possession of Characterization Engineering, Maintenance, and Operations organizations assigned 
stewardship responsibilities for the RT and TT. Engineering will maintain the electronic data sets, (CAD files), for the drawings in accordance with RPP-PRO1819, "Engineering Requirements" and RPP-PRO-709, "Preparation and Control Standards For Engineering Drawings". Any RT or TT drawings that need to be created, whether new or modified from original vendor drawings, will be added to the "Long Length Contaminated Equipment Retreival System Trailers Drawings" supporting document.

The Requirements baseline for the LLCERS RT and TT is defined by:

WHC-S-0321, Rev. 0, "Specification For LLCE Trailer System".

The Operations baseline for the LLCERS RT and TT is defined by:

RPP-6190, "Long Length Contaminated Equipment Retreival System Receiver Trailer and Transport Trailer Operations and Maintenance Manual". Operations and maintenance discussions/instructions make reference to various "labels" affixed to RT and TT subsystems, equipment, and components.

HNF-3252 provides, "General Maintenance Instructions for LLCE Transportation System". HNF-3069 provides, "General Operating Instructions for LLCE Transportation System". HNF-3071 provides, "Preparation and General Operating Instructions for LLCE Receiver Trailer". HNF-3070 provides, "Preparation and General Operating Instructions for LLCE Transport Trailer".

RPP-5696, "Long Length Contaminated Equipment Maintenance Plan".

Configuration change control will be accomplished by Engineering Change Notice $(\mathrm{ECN})$, direct revision page changes to these supporting documents.

\subsection{COMMENTS}

It should be noted that configuration management is applied in a graded manner for many items of Tank Farms special equipment, such as cranes, oiler trucks, etc. This Configuration Management Plan for the RT and TT considers both the equipment complexity and the interfaces with Tank Farms installed systems and equipment.

Note, the RT does not interface directly with the waste tank (a non-reactor nuclear facility), but with the crane which lifts the equipment from the tank. The TT does not interact with the crane or the waste tank.

A second item of note is that typical RPP past practice has been to perform virtually all Configuration Management activities in the same manner as that performed for permanent, non-reactor nuclear facilities. In some cases it may have been cost-effective, but not necessary. In this instance (the case of the RT and TT) the cost benefit gained by controlling the configuration in the alternate and adequate method described is warranted. 


\subsection{REFERENCES}

WHC 1995, Specification for the Handling and Transport of Tanks Farms Long-Length Contaminated Equipment - WHC-S-0321, Rev. 2-B, Westinghouse Hanford Company, Richland, Washington.

CHG 1999a, PHMC Engineering Requirements, RPP-PRO-1819, Rev. 0, CH2M HILL Hanford Group, Inc., Richland, Washington.

CHG 1999b, Preparation and Control Standards For Engineering Drawings, RPP-PRO0709, Rev. 0, CH2M HILL Hanford Group, Inc., Richland, Washington.

CHG 2000a, Long Length Contaminated Equipment Retreival System Receiver Trailer and Transport Trailer Operations and Maintenance Manual - RPP-6190, CH2MHILL Hanford Group, Inc., Richland, Washington.

CHG 2000b, Long Length Contaminated Equipment Retreival System Trailers Drawings - RPP-6189, CH2MHILL Hanford Group, Inc., Richland, Washington.

CHG 2000c, RPP Administration Manual, HNF-IP-0842, Volume IV, Section 3.5, "Engineering Documents", CH2M HILL Hanford Group, Inc., Richland, Washington.

CHG 2000d, RPP Administration Manual, HNF-IP-0842, Volume IV, Section 4.23, "Vendor Information", CH2M HILL Hanford Group, Inc., Richland, Washington.

CHG 2000e, RPP Administration Manual, HNF-IP-0842, Volume IV, Section 4.24, "Design Verification", CH2M HILL Hanford Group, Inc., Richland, Washington.

CHG 2000f, RPP Administration Manual, HNF-IP-0842, Volume IV, Section 4.25, "Engineering Drawings", CH2M HILL Hanford Group, Inc., Richland, Washington.

CHG 2000g, RPP Administration Manual, HNF-IP-0842, Volume IV, Section 4.29, "Engineering Document Change Control Requirements", CH2M HILL Hanford Group, Inc., Richland, Washington.

CHG 2000h, "Long Length contaminated Equipment Maintenance Plan" RPP-5696, CH2MHILL Hanford Group, Inc., Richland, Washington.

CHG 2000i Engineering Task Plan (ETN-98-0007) Stewardship of LLCERS, RPP-3654, CH2MHILL Hanford Group, Inc., Richland, Washington. 
HNF 1997 "Safety Analysis Report for Packaging (Onsite) Long Length Contaminated Equipment", HNF-SD-TP-SARP-013, Rust Federal Services Inc. Northwest Operations, Richland, Washington.

HNF 1998a "General Maintenance Instructions for LLCE Transportation System", HNF-3252, CH2MHILL Hanford Group, Inc., Richland, Washington.

HNF 1998b "General Operating Instructions for LLCE Transportation System", HNF3069, CH2MHILL Hanford Group, Inc., Richland, Washington.

HNF 1998c "Preparation and General Operating Instructions for LLCE Receiver Trailer”, HNF-3071, CH2MHILL Hanford Group, Inc., Richland, Washington.

HNF 1998d "Preparation and General Operating Instructions for LLCE Transport Trailer", HNF-3070, CH2MHILL Hanford Group, Inc., Richland, Washington. 